\title{
Social disparity in magnifying glass: the inequality among the vulnerable people during COVID-19 pandemic
}

\author{
Andre Luis Ribeiro Ribeiro ${ }^{1}$, Naama Waleria Alves Sousa ${ }^{1}$, and Vitor Oliveira Carvalho ${ }^{2}$ \\ ${ }^{1}$ INCOM - Instituto de Cirurgia Oral e Maxilofacial \\ ${ }^{2}$ Federal University of Sergipe
}

May 21, 2020

\section{Social disparity in magnifying glass: the inequality among the vulnerable people during COVID-19 pandemic}

Keywords: COVID-19; SARS-COV-2; social disparity; vulnerable people

The editorial written by Stein and Ometa, (2020) [1] about the dilemma between health system and socioeconomic conditions created by the Covid-19 pandemic has called our attention as a very appropriated topic. Indeed, there are different repercussion in all aspects in unequal societies, which goes from financial issues to the chances to adhere of the current recommended measures of the WHO. For instance, social distancing and basic personal hygiene without proper social, economic and healthcare support may contribute to exacerbate disparity in fragile societies.

In Brazil, the virus SARS-COV-2 is spreading fast and crashing our healthcare system and economy. The government is struggling to pay the financial supporting defined by the congress of 600 Brazilian real per month (about 100USD) for all the living costs and only reached around $15 \%$ of the population.

Demographic data show that $48 \%$ of Brazilians live in places without sewage and 35 million do not have access to running water in their homes [2]. Furthermore, $5-10 \%$ live in slum-like areas known as "favelas" [3], where most residences accommodate an average of 5 individuals per room with a housing density 10x higher than the rest of the city [4]. Finally, $40.6 \%$ of the Brazilian working-age population are in the informal economy, living without social protection [5]. Keeping these in mind, how can these vulnerable people protect themselves in times of COVD-19? How can they keep basic hygiene without regular running water and sewage? How to accomplish social distancing living in over-crowded places?

If the COVID-19 wasn't challenging enough, Brazil still struggles with other important infectious diseases, such as Dengue fever, Zika e Chikungunya. These viral mosquito-borne infections (Aedes aegypti mosquito) are endemic in Brazil and can show initial similar signs and symptoms to COVID-19. The rainy season is the most favourable time for mosquito proliferation and disease spread [6], which this year the seasonality (usually peaks in April) is coinciding with the spread of SARS-COV-2 in Brazil [7]. Socially vulnerable people are more prone to acquire Aedes aegypti-related infections due to poor housing, poor sanitation and high-density population housing in "favelas" [8] [9].

Current recommendations for people with COVID-19 mild illness is to stay at home. However, the panic-state created by the COVID-19 pandemic is taking these vulnerable people, which may be suffering of mosquitoborne infections, to health units and exposing them to SARS-COV-2. Thus, the overlapping of infections is overburdening even more the health system and increasing the transmission rate of COVID-19 in Brazil. Furthermore, many people in the informal market don't have bank accounts and are agglomerating in huge lines in bank branches to get the financial aid. While many developed countries have struggled to give 
assistance to COVID-19 patients, Brazil must battle against two powerful enemies. So, the hard question to answer is: how many extra souls will be lost due to Brazil's chronic problems?

Brazil was used as an example we know well, but many other non-developed countries, especially the African ones may be struggling with some of these problems as well.

\section{Conflict of interests}

The authors declare that they have no known competing financial interests or personal relationships that could have appeared to influence the work reported in this paper.

\section{Funding}

The authors declare that they have no funding source to influence the work reported in this paper.

\section{REFERENCES}

[1] R. A. Stein and O. Ometa, "When Public Health Crises Collide: Social Disparities and COVID-19," Int. J. Clin. Pract. , pp. 0-2, May 2020. doi:

\subsection{1/IJCP.13524}

[2] S. Federal, "Brasil tem $48 \%$ da populacao sem coleta de esgoto, diz Instituto Trata Brasil — Senado Noticias," 2020. [Online]. Available: https://www12.senado.leg.br/noticias/materias/2019/09/25/brasiltem-48-da-populacao-sem-coleta-de-esgoto-diz-instituto-trata-brasil.

[3] C. Boehm, "Moradores de favelas movimentam R \$119,8 bilhoes por ano," Empresa Brasil de Comunicacao , 2020. [Online]. Available: https://agenciabrasil.ebc.com.br/geral/noticia/2020-01/moradores-de-favelasmovimentam-r-1198-bilhoes-por-ano. [Accessed: 19-May-2020].

[4] B. Souza, "Junto e misturado - Data Labe," data_labe , 2020. [Online]. Available: https://datalabe.org/junto-e-misturado-isolamento-e-quarentena-sao-possiveis-nas-favelas/. [Accessed: 25May-2020].

[5] A. Nitahara, "Informalidade cai , mas atinge 38 milhoes de trabalhadores," Empresa Brasil de Comunicacao , 2020. [Online]. Available: https://agenciabrasil.ebc.com.br/economia/noticia/2020-03/informalidadecai-mas-atinge-38-milhoes-de-trabalhadores. [Accessed: 19-May-2020].

[6] Ministerio da Saude, "Combate ao Aedes Aegypti: prevencao e controle da Dengue, Chikungunya e Zika," Ministerio da Saude, 2020. [Online]. Available: https://www.saude.gov.br/saude-de-a-z/combate-ao-aedes. [Accessed: 20-May-2020].

[7] D. V. Viana and E. Ignotti, "The ocurrence of dengue and systematic review," Rev Bras Epidemiol, vol. 16, no. 2, pp. 240-256, 2013.

[8] J. Heukelbach, F. A. Sales De Oliveira, L. R. S. Kerr-Pontes, and H. Feldmeier, "Risk factors associated with an outbreak of dengue fever in a favela in Fortaleza, north-east Brazil," Trop. Med. Int. Heal. , vol. 6, no. 8, pp. 635-642, 2001.

[9] R. Maciel-de-Freitas, R. Souza-Santos, C. T. Codeco, and R. LourencO-De-Oliveira, "Influence of the spatial distribution of human hosts and large size containers on the dispersal of the mosquito Aedes aegypti within the first gonotrophic cycle," Med. Vet. Entomol. , vol. 24, no. 1, pp. 74-82, 2010. 